\title{
ORGANIZATIONAL CITIZENSHIP BEHAVIOUR AND THE MEDIATING ROLE OF ORGANIZATIONAL COMMITMENT: A STUDY OF PRIVATE UNIVERSITIES
}

\author{
Sofiah Kadar Khan* \\ Quest International University Perak \\ Mumtaz Ali Memon \\ National University of Sciences and Technology, Islamabad
}

\author{
Alex Cheing \\ Briercrest College \\ Hiram Ting \\ UCSI University
}

\begin{abstract}
This study aims to perpetuate the investigation of organizational commitment and its mediating role as it is one of the most crucial components in understanding organizational behaviour. A total of 324 samples were collected from the academics of 20 private universities in Malaysia. Partial Least Squares Structural Equation Modelling (PLS-SEM) using SmartPLS3.0 was used to perform the latent variable analysis. The results indicate transformational leadership, organizational culture, and organizational justice are the significant predictors of organizational commitment, and organizational commitment, in turn, is found to be a strong predictor of organizational citizenship behaviour. Moreover, the results of mediating analysis highlight that organizational commitment significantly mediates the hypothesized relationship. The implications of the findings are discussed and recommendations for future research are proposed.
\end{abstract}

Keywords: Organizational Commitment, Organizational Citizenship Behaviour, Culture, Justice, Transformational Leadership, Higher Education Institutions.

Received: 18 February 2019

Accepted: 31 December 2020

https://doi.org/10.33736/ijbs.3160.2021

\section{INTRODUCTION}

Organisational Citizenship Behaviour (OCB), a voluntary behaviour that enhances an organization's effectiveness through employees' commitment, continues to be of relevance in a contemporary environment (Messner, 2013; Podsakoff, Whiting, Podsakoff \& Blume, 2009). Such behaviour is closely associated with social exchange theory which essentially describes an expectation to return favor through a sense of personal obligation (Blau, 2009). Given the

- Corresponding author: Sofiah Kadar Khan, Quest International University, Plaza The Teng Seng,227 Jalan Raja Permaisuri Bainun, 30250, Ipoh; Tel: 05-2490500; Email: sofiahkadarkhan@ gmail.com 
increased diversity within the organization and the complexity, any attempts to unbalance reciprocity may create conflicts and impair commitment in organizations (Lau, McLean, Lien, \& Hsu, 2016).

Competition among universities in attracting students has posed questions on whether higher education institutions should strategize like business organizations to achieve a competitive and distinctive advantage. (Alondenene \& Majauskaite, 2016). Hence, there has been an expansion of academic research on positive work outcomes in higher education institutions (Bryman, 2007) stemming from the benefits of OCB (Asgari, Silong, Ahmad, \& Samah, 2008; Farzaneh, Farashah, \& Kazemi, 2014). Past studies had disclosed that organizational culture, transformational leadership, and organizational justice have profound impacts towards OCB and organizational performance (Silverthorne, 2004; Joo, Yoon \& Jeung, 2012; Alfy \& David, 2017) even though the variables have not been tested together. It is important to understand organisation culture because each component suggested in organisation culture can encourage or discourage positive behaviours among employees such as innovative culture. Innovative culture elevates creativity (Yiing \& Ahmad, 2009). Transformational leadership has been emphasized and studied extensively in leadership literature due to its nature in motivating and inspiring employees to change. Private universities need to compete extensively, and changes are inevitable. The transformative nature in transformational leadership can lead employees towards adaptability of changes and has the ability to amplify the inherent traits of employees' positive behaviours (Khalili, 2017). Organisation justice on the other perspective stresses on the aspect on how fairly faculty members are treated. The fairness implemented is able to cultivate positive behaviours among employees and ensure they stay motivated in providing optimal service in the private higher education in which they are employed. (Alfy \& David, 2017).

A crucial factor which can have an influence on OCB is organizational commitment (Mohammad, Quoquab, Makhbul, \& Ramayah, 2016; Ortiz, Rosario, \& Marquez, 2015). Employees who have high levels of organizational commitment are more likely to excel (Ortiz et al., 2015; Perryer \& Jordan, 2010) which is reflected in a higher correlation between attitudinal commitment and performance. Past studies had incorporated organizational commitment as an independent variable influencing organizational performance (McCurdy, 2014; Bashir \& Long, 2015; Flinders \& Rauters, 2008) or as a dependent variable which is affected by other antecedent variables. In view of this situation, it was contended that organizational commitment should be treated as a key mediating variable in determining organizational outcomes (Altintas, Kurtulmusoglu, Altintas, Kaufmann, \& Alkibay, 2017).

Malaysia has arguably one of the most competitive higher education sectors in the Asia Pacific, with growing numbers of the new educational establishment including foreign-based campuses of various well-known international universities and colleges. This study attempts to fill the gap in the literature by focusing on the mediating role of organizational commitment that supports OCB among faculty members in Malaysian private universities which remained under-researched to date in comparison with primary and secondary education (Barbuto \& Story, 2011; Lazauskaite, Urbanaviciute, \& Bagdziuniene, 2015). Our study has extended further the perspective in comprehending OCB. OCB is a behaviour which is demonstrated voluntarily and there is no reward incorporated. It has been widely studied in corporate organisations. However, there is lack of research in the context of educational institutions (Lazauskaite et al., 2015). In understanding what provokes this positive behaviour among Malaysian academics may 
contribute significantly to the success of private universities in achieving its vision. This study proposes that organizational commitment will be strengthened if organizational culture, transformational leadership, and organizational justice existed in positive work condition (Organ, Podsakoff, \& MacKenzie, 2006; Blau, 2009). Furthermore, we are also proposing in incorporating organisational commitment as a mediator or a form of facilitator as commitment has shown a considerable amount of effect towards positive behaviour (Keskes, Sallan, Simo, \& Fernandez, 2018; Uddin, Mahmood, \& Fan, 2019).

The hypotheses are developed in the next section. We then describe the methods used in the present study. Next, we describe the analysis and results, followed by an explanation of the findings and their implications before concluding the present study.

\section{LITERATURE REVIEW}

\subsection{Organizational Culture}

Organizational culture is defined as a pattern of basic assumptions invented, discovered or developed by a given group in order to cope with external and internal equilibrium (Schein, 2004). It is typically hierarchical or supportive in nature, as evidenced by organizational culture index developed by Wallach (1983) which are made up of bureaucratic, innovative and supportive traits. The influence of organizational culture on organizational commitment in different settings has shown a significant correlation (Yiing \& Ahmad, 2009), justifying its role in creating positive work attitudes. In general, an organizational culture which promoted teamwork, innovativeness, minimal hierarchy and sense of freedom exemplified better work outcomes (Yiing \& Ahmad, 2009; Silverthorne, 2004).

Organizational culture is an amalgamation of the atmosphere created by social and professional interactions in determining what the institution is capable of achieving (Trivellas \& Dargenidou, 2009) specifically in deriving organizational commitment among employees towards achieving common objectives. Many higher education institutions exhibited unique organizational culture through an emphasis on knowledge (Vasayakin, Iveleva, Pozharskaya, \& Shcherbakova, 2016). Additionally, these institutions followed different competitive trajectory due to higher anticipation on creativity levels among faculty members and current cohort of students who are mostly millennials (Zhu \& Engels, 2017). An organisation culture which promotes minimal hierarchy and an increased sense of freedom and team promotes positive work outcomes (Messner, 2013). In broadening our view in understanding organisation culture it has been suggested that innovative culture has the ability to encourage employees to maintain an acceptable level of quality standards as compared to bureaucratic and supportive culture (Ababaneh, 2010). Innovative culture among all the three cultures has the most dominant effect in encouraging creativity thinking which can further be implemented with good supervisory support and flexibility (Ababaneh, 2010).Employees volunteering behaviour is a choice made by employees without any form of reward from the organisation and it is possible that organisation culture has the ability to evoke this behaviour which has proven to be beneficial (Jain, 2016). 
The relationship between organizational culture and organizational commitment has been found associated (Yiing \& Ahmad, 2009; Silverthorne, 2004) but there are limited empirical studies on its effect in Malaysian private universities. As such we propose the following hypothesis :

\section{H1: Organizational culture is associated with organizational commitment.}

\subsection{Transformational Leadership}

A transformational leadership style focuses on examining organizational outcomes by identifying leaders' behaviour and how the relationship between leaders and subordinates were formed (Graen \& Uhl-Bien, 1995). The elements in transformational leadership included vision, inspirational communication, intellectual stimulation, supportive leadership and personal recognition (Joo et al., 2012; Lapierre \& Hackett, 2007; Lee, 2005). These provided a strong foundation in leadership style towards cultivating trust among employees in developing a positive relationship (Rafferty \& Griffin, 2004; Lee, 2005). A transformational leadership which fixated on one-to-one mutual social exchange in nurturing a dyadic relationship could easily build trust which in turn promoted OCB (Joo et al., 2012; Lo, Ramayah, \& Kueh, 2006) which includes many higher education institutions (Khan \& Rashid, 2012; Geijsel, Sleeger, Leithwood, Jantzi, 2003; Pillai \& Williams,2004). The changing nature in education especially private higher education demands the influence of leadership. It is vital for leaders to possess the qualities to elevate positive behaviours and be a component in transforming the mindsets of employees to ensure that changes are blended in appropriately (Khalili, 2017; Jain, Giga, \& Cooper, 2013). Transformational leadership has been highly regarded in the understanding leadership as compared to transactional leadership due to its motivating mechanisms. In addition to that because of its paramount effect in terms of theoretical, empirical support and highest validity as compared to other forms of leadership (Gyensare, Tsede, Sanda, \& Okpoti, 2016). Considering the effect of transformational leadership on the facets of understanding organisational commitment and OCB in the context of collectivist society there is very little evidence in literature particularly in Malaysia among private university leaders. A leadership style which holds components with the ability to promote a working environment where personal stimulation and vision orientation is emphasized encourages positive behaviour (Mekpor \& Baah, 2017). Leadership style based on communicating elements such as inspiring vision to followers, stimulating intellectual stimulation elevates organisation commitment and positive work behaviours. It has further elaborated that actions of a leader is able to increase commitment towards the organisation and committed employees are more likely to exhibit behaviours which will benefit the organisation (Keskes et al., 2018).

Khalifa and Ayoubi (2015) projected that distinctive leadership styles are more appropriate for faculty members in higher education institutions in comparison with administrative staff. This echoed past findings which confirmed that the effect of leadership style towards organizational commitment was divergent based on organizational culture (Li, 2004). Additionally, organizational commitment might be able to mediate the relationship between leadership behaviour and organizational performance but the degree of effect in this mediating mechanism is dependent on leadership and organizational culture (Abi \& Arief, 2017). In this regard, we propose the following hypothesis:

H2: Leadership style (transformational) is associated with organizational commitment. 


\subsection{Organizational Justice}

Generally, organizational justice is defined as employees' perception of how the organization treats them. It contained elements of procedural justice, distributive justice, and interactional justice. Distributive justice is perceived fairness in the outcomes and procedural justice is the fairness of procedures used in order to allocate resources. In contrast, interactional justice is the emphasis of the interpersonal aspect of organizational practices (Glinow, 2010). Previous studies stipulated a strong relationship between organizational justice and OCB through perceptions of fair procedural implementation in an organization (Choong, Wong, \& Tioh, 2010; Hassan \& Hashim, 2011). It is commonly agreed that trust is easily gained through organizational justice when employees have a positive perception in their mindset (Mohammad et al, 2016; Pilai \& Williams, 2004).

To demonstrate this point, it is vital to nurture a positive educational environment for faculty members by implementing fair procedures to ensure that they remain motivated and maximize their full potential (Alfy \& David, 2017). In addition, policymakers in higher educations need to understand that faculty members are from diverse groups and perception of fairness may vary in terms of resource allocations and culture. Hence, it has to be strategically implemented to elevate positive work behaviour (Malik \& Naeem, 2011).

Malaysian employees typically showed OCB when they perceived their organizations as reasonable (Mohammad et al., 2016). For example, faculty members are prone to show a higher trust level working under leaders who are nonpartisan (Hoy \& Tarter, 2004). This trust among faculty members resulted in organizational commitment and shaped a more caring workplace environment (Bashir \& Long, 2015). Consequently, the following hypothesis is proposed:

\section{H3: Organizational justice is associated with organizational commitment.}

\subsection{Organizational Commitment as a Mediator}

Organizational commitment is identified in three distinct terms: affective, normative and continuance commitment (Meyer \& Allen, 1997). Affective commitment is an employee's emotional attachment to the organization; normative commitment is employee's obligation to remain while continuance commitment is prolonged extension of employment by employees to avoid social or economic hardships that may result from termination (Flinders \& Rauters, 2008; Liu, 2009). The prevailing point of view in the field is that there is a substantial relationship between organizational commitment and OCB, in the form of loyalty attachment (Farzaneh et al., 2014; Messner, 2013).

Likewise, previous studies had firmly connoted that organizational commitment was able to enhance organizational performance (McCurdy, 2014; Farzaneh et al., 2014). The prominence of organizational commitment in eliciting citizenship behaviour among employees resulting in organizational effectiveness is well-known (Farzaneh et al., 2014; Ortiz et al., 2015). Above all, organization commitment is not 'embedded' in an individual when he or she joins an organization but it is was acquired through the former's perceptions of the work environment and communal reciprocity (Farzaneh et al., 2014; Ng \& Feldman, 2011). A Malaysian-based study by Tan, Zawawi, and Aziz (2016) has reiterated the dominance of benevolent-style management 
towards initiating positive changes in an organization. In particular, organizational commitment is found to have a full mediating effect on the relationship between leadership style and OCB.

The studies above have established the direct impact of organizational commitment thereby its effect as a mechanism to mediate the relationship has been the core focus of our study. To date, little empirical research has been done to investigate the relationships of the stipulated constructs and its outcomes in the Malaysian higher education context. Yiing \& Ahmad, (2009) claimed that a leader's style was found to have a positive and momentous effect with organizational commitment. More specifically, it was discovered that an organizational culture setting has an eloquent effect towards organizational commitment. The three independent variables suggested in our study: i) organizational culture, ii) transformational leadership style, and iii) organizational justice has proved to possess a positive effect towards OCB as mentioned in previous literature.

Despite the extensive literature on organizational commitment its role as a mediator has not been studied extensively especially in a collectivist culture such as Malaysia. Previous findings (Chang, Nguyen, Cheng, Kuo \& Lee, 2016; Bashir \& Long, 2015) advocated that benefits derived by faculty members were likely to influence their attachment towards their institution mainly due to social exchange theory whereby the provision of a good environment in terms of leaders and peers support led to compassion. Due to these reasons, faculty members became more committed to their work in view of the psychological contract being fulfilled by both parties. Essentially, faculty members who were consulted during decision making were found to be more devoted by providing better service to students (McCurdy, 2014). For one thing, the impact of training was also found to be relevant towards faculty members' loyalty and attachment as it was an indicator that the higher education institution recognized their contribution (Bashir \& Long, 2015). The positive effect of organisation as a mediator was also empirically tested for sales performance. The study indicated that by applying commitment as a mediator to study its significance towards sales performance it evidenced a positive result.(Altintas et al., 2017). The positive benefits of organisation commitment are not only seen towards the organisation but its ability can be further elaborated in how it increases team work. Highly committed employees are seen to be more engaged and seem to demonstrate more proactive behaviour to support organisation objectives (Uddin et al., 2019). Committed employees tend to have the ability to demonstrate better teamwork which benefits the organisation in terms of achieving its objectives (Uddin et al., 2019).

In other words, these patterns further augmented the significance of organizational culture towards organizational commitment (Yiing \& Ahmad, 2009; Silverthorne, 2004); transformational leadership style towards organizational commitment (Joo et al, 2012; Geijsel et al., 2003) and organizational justice towards organizational commitment (Alfy \& David, 2017; Choong et al., 2010). Presently, limited empirical studies examining these relationships in a joint effect with organizational commitment as a mediator towards OCB existed, leading to the following hypothesis:

H4: Organizational commitment is associated with $O C B$ 


\subsection{Organisational Citizenship Behaviour}

Employees' with high level of OCB go beyond their formal roles and voluntarily offer their support to the organisation (Memon, Sallaeh, Baharom, Nordin, \& Ting, 2017). According to (Podsakoff et al., 2009), there are five dimensions in OCB namely altruism, courtesy, sportsmanship, civic virtue, and conscientiousness Altruism is present when employees collaborated in workforce tasks. Courtesy involved treating fellow co-workers with respect while sportsmanship existed when employees maintained positive attitudes despite challenging circumstances. Civic virtue occurred when concerns arose with the welfare of the organization and conscientiousness included discretionary behavior that went well beyond the minimal requirement of employers.

To sum up, employees are motivated to perform because they want to nurture co-workers which in turn triggers work satisfaction. In the same way, OCB is frequently displayed in situations where employees are not under supervision (Barbuto \& Story, 2011; Lazauskaite et al., 2015; Ozduran \& Tanova, 2016). OCB studies conducted in educational settings amplify its rhetorical consequence in the psychological environment (Somech \& Bogler, 2005). Similarly, OCB among faculty members is expressed in their desire to assist students, voluntary efforts, and team contribution. This is manifested when empowerment and self- efficacy are present among them further contributing to the practical importance of OCB (Podsakoff \& Mackenzie, 1997; Somech \& Drach-Zahavy, 2004).

It has been further claimed that management's behavior has a strong influence on positive work outcomes among faculty members (Amzat \& Idris, 2010), resulting in positive OCB (Kagaari \& Munene, 2007). It is thus necessary to comprehend what mediates OCB among faculty members to further enhance the performance of higher education institutions. Past study shows that placing academic citizenship in education sector will create more citizenship-oriented faculty members (Macfarlane, 2007). In like manner, students will be benefited greatly when faculty members demonstrate OCB (Oplatka, 2009) as a result of relational trust in response to the tenet of social exchange theory (Elstad, Christophersen, \& Turmo, 2012).

Our study intends to expand the effects of the mediating mechanism of organizational commitment of faculty members towards OCB to reiterate social exchange theory and its reciprocal process. Although past studies related to organizational commitment mostly specify such commitment as an independent variable (Ortiz et al., 2015; Farzaneh et al., 2014), it could be an important mechanism when dealing with management issues (Mathieu, 1990). Likewise, studies related to incorporating organization commitment as a mediator recognize its effect in increasing employee performance but less towards employee commitment (Suliman, 2002).

In the same way, Li (2004) advocated that the mediating effect of organizational commitment is dependent upon leadership and organizational culture. It is assumed that employees in collectivist culture may exhibit increased loyalty to their in-group and formed stronger ties with their organizations (Jain, 2016; Hofstede, Hofstede \& Minkov, 2010). For example, the positive relationship of organizational commitment may not be consistent as the results are found to be different in Thai culture (collectivist) and American (individualistic) (Limpanitgul \& Boonchoo, 2017; Hofstede, Neuijen, Ohayy, \& Sanders, 1990). So, we anticipate that the joint effect of these 
constructs elevates OCB in organizations and understanding organizational commitment should not be restricted to a single cultural domain.

Yiing \& Ahmad, (2009) argued that when employees are not satisfied at work, they are less committed and would search for job opportunities elsewhere since they have mentally "withdrawn" from the organization. This would deter them from displaying positive work behaviour. We, therefore, contend that by addressing employees' needs in organizational factors, which are consisted of organizational culture, transformational leadership and organizational justice would foster organizational commitment towards OCB.

An organizational culture which concentrates on minimal hierarchy tends to promote positive work outcomes (Farzaneh et al., 2014; Messner, 2013) through a better understanding of stakeholders' relationship (Vasayakin et al, 2016). In contrast, a study conducted in India (Jain, 2016) discovered that organization culture does not have any impact on OCB due to the dominance of male respondents in a typical Indian workplace. This diverges from transformational leadership style which will increase positive employees' behaviours in higher education institutions through the policy of fairness (Alfy \&David, 2017; Joo et al, 2012).

Overall, organizational commitment has been studied extensively on its direct effect on various contexts and its positive effect has remained consistent. On the other hand, if the perception is not favorable then it will contribute towards a less desired performance (Suliman, 2002). Although there are not many studies on the mediating relationship of organization commitment towards OCB, it can be reasoned that organization commitment as a mediator between organization culture, transformational leadership style, and organization justice can generate positive work behaviour. Hence the following hypotheses are put forward:

H5: Organizational commitment mediates the relationship between organizational culture and $O C B$.

H6: Organizational commitment mediates the relationship between transformational leadership and $O C B$

H7: Organizational commitment mediates the relationship between organizational justice and $O C B$

\section{RESEARCH METHODOLOGY}

A letter of invitation was sent to 28 private universities followed by phone reminder, where 20 agreed to participate. A total of 1926 questionnaires were distributed to faculty members. The study used convenience sampling with fair distribution based on the availability of participants without specific targeting specific faculty or course. Three hundred and twenty-four (324) useable questionnaires were returned with a response rate of $16.8 \%$. 


\subsection{Respondents profile}

A total of 177 respondents (majority) or 54.6\% were aged between 25 and 34 while 73 respondents or $22.5 \%$ were aged between 35 and 44 . A total of 195 respondents were male. In terms of salary, 149 respondents (46\%) earned an income of less than RM 4,000. Malaysians accounted for the majority of the respondents (312 or 96.3\%) while the rest were expatriates. In terms of ethnicity, the largest number of respondents was Malays, 137 (42.3\%), and the least were others, which is seven $(2.2 \%)$. A total of 206 respondents $(63.6 \%)$ were at lecturer rank with the remaining four at professor rank $(1.2 \%)$. Those having between one and three years of teaching experience accounted for the largest number at 111 (34.3\%) followed by $96(29.6 \%)$ who had between four and six years, $69(21.3 \%)$ had ten years and above and $15(4.6 \%)$ had less than one year.

The research utilized and modified the instruments according to five constructs of OC, LS, OJ, organizational commitment and OCB. Firstly, OC was adapted from the original Organisational Cultural Index (OCI) scale developed by (Wallach, 1983). Secondly, LS was measured by the scale developed by Bass's Multifactor Leadership adapted from Asgari et al., (2008) including MLQ-Form 5 originated from Rafferty and Griffin (2004). Thirdly, OJ was measured using questions adapted from Asgari et al., (2008) from the Malaysian perspective which consisted of procedural justice, distributive justice, and interactional justice. Fourthly, organizational commitment was measured using questions adapted from Meyer and Allen (1997) comprising three components: affective commitment, continuance commitment, and normative commitment. Finally, the measurement scale for OCB was adapted from Podsakoff and Mackenzie (1997) containing five dimensions of altruism, courtesy, sportsmanship, civic virtue, and conscientiousness. The selected measurement scales have exposed satisfactory validity and reliability in previous studies.

The questionnaires comprised two sections: Section A covered the demographic section of the respondents whereby Section B comprised questions related to the five variables examined in this study. Data were obtained from self-administered questionnaires. There were 101 questions related to the five constructs and 13 questions on demography. The elements in transformational leadership included vision, inspirational communication, intellectual stimulation, supportive leadership, and personal recognition. A pre-test session was conducted to revise ambiguous and unclear items (Memon, Ting, Ramayah, Chuah, \& Cheah, 2017).

\section{RESULTS}

\subsection{Partial Least Squares Structural Equation Modelling}

The Partial Least Squares Structural Equation Modelling (PLS-SEM) method using SmartPLS3.0 (Ringle, Wende, \& Becker, 2015) was employed to test the hypothesized model. PLS-SEM is highly recommended for complex modeling, mediating models in particular (Nitzl, Roldan, \& Carrion, 2016). Given that the present study was set to examine the mediating role of organizational commitment between antecedents (leadership, culture, and justice) and OCB, PLS-SEM was considered a suitable method of data analysis. A two-stage approach including 
measurement model (internal consistency reliability, convergent validity, and discriminant validity) and structural model (hypothesis testing) was adopted to test the prescribed hypotheses (Anderson \& Gerbing, 1988; Ramayah, Cheah, Chuah, Ting, \& Memon, 2018).

\subsection{Measurement Model Assessment}

Measurement model is confirmed through internal consistency reliability, convergent validity and discriminant validity (Hair, Hult, Ringle, \& Sarstedt, 2017). Internal consistency reliability indicates whether the items used in the study are reliable, can be confirmed through composite reliability (CR) (McNeish, 2017). A CR value of 0.7 and above is considered satisfactory (Ramayah, Cheah, Chuah, Ting, \& Memon, 2016). The results point out that all constructs have achieved satisfactory results; OCB (0.920), justice (0.951), leadership (0.922), organization culture (0.913) and organizational commitment (0.874).

Next, convergent validity (CV) is determined through the average variance extracted (AVE). CV assesses the "extent to which a measure correlates positively with alternative measures of the same construct" (Hair, Hult, Ringle, \& Sarstedt, 2014). In order to achieve a satisfactory outcome, a construct must show AVE 0.5 (50\%) (Hair et al., 2017). Although the first run of analysis does not achieve threshold value, exclusion of items with low loadings results in the desirable results. The results indicate OCB (0.536), justice (0.532), leadership (0.664), organizational culture (0.569) and organizational commitment $(0.635)$, thus confirming the $\mathrm{CV}$ of the model (Table 1).

Table 1: Results of Measurement Model

\begin{tabular}{lcccc}
\hline \hline \multicolumn{1}{c}{ Latent Constructs } & $\begin{array}{c}\text { Loadings } \\
\text { (Range) }\end{array}$ & AVE & CR & $\begin{array}{c}\text { Convergent } \\
\text { Validity }\end{array}$ \\
\hline Commitment & $0.639-0.793$ & 0.635 & 0.874 & Yes \\
Justice & $0.650-0.789$ & 0.532 & 0.951 & Yes \\
Transformational Leadership & $0.715-0.859$ & 0.664 & 0.922 & Yes \\
OCB & $0.627-0.845$ & 0.536 & 0.920 & Yes \\
Organizational Culture & $0.736-0.848$ & 0.596 & 0.913 & Yes \\
\hline \hline
\end{tabular}

The Heterotrait-monotrait ratio of correlations (HTMT) is used to assess the discriminant validity (DV), a conservative approach for assessing DV (Henseler, Ringle, \& Sarstedt, 2015). DV refers to the "extent to which as a construct is truly distinct from other constructs by empirical standards" (Hair et al., 2017). For a satisfactory level of DV, an HTMT value should not be more than 0.90. An HTMT value above 0.90 highlights a lack of DV which show that the constructs are conceptually identical. The results of the present study listed HTMT is fixed at HTMT.90; all constructs have HTMT scores less than 0.90, indicating that all constructs measure distinctive domains. The results of the DV are presented in Table 2. 
Table 2: HTMT Results

\begin{tabular}{|c|c|c|c|c|c|}
\hline Latent Constructs & 1 & 2 & 3 & 4 & 5 \\
\hline 1. Commitment & & & & & \\
\hline 2. Justice & $\begin{array}{l}0.788 \\
{[0.526} \\
0.880]\end{array}$ & & & & \\
\hline $\begin{array}{l}\text { 3. Transformational } \\
\text { Leadership }\end{array}$ & $\begin{array}{l}0.701 \\
{[0.490} \\
0.810]\end{array}$ & $\begin{array}{l}0.802 \\
{[0.728} \\
0.896]\end{array}$ & & & \\
\hline 4. OCB & $\begin{array}{l}0.575 \\
{[0.412} \\
0.692]\end{array}$ & $\begin{array}{l}0.609 \\
{[0.584 ;} \\
0.814]\end{array}$ & $\begin{array}{l}0.562 \\
{[0.500 ;} \\
0.634]\end{array}$ & & \\
\hline 5. Org. Culture & $\begin{array}{l}0.62 \\
{[0.540} \\
0.726]\end{array}$ & $\begin{array}{l}0.633 \\
{[0.614 ;} \\
0.698]\end{array}$ & $\begin{array}{l}0.675 \\
{[0.590} \\
0.718]\end{array}$ & $\begin{array}{l}0.565 \\
{[0.480} \\
0.682]\end{array}$ & \\
\hline
\end{tabular}

\subsection{Structural Model Assessment}

Upon confirmation of the measurement model, assessment of structural model is used to assess the theoretical relationships between the latent constructs. The coefficient of determination $\left(R^{2}\right)$, path coefficient (beta), and effect size $\left(f^{2}\right)$ are evaluated. Bootstrapping method using 5000 resamples is employed to confirm the significance of the relationships. $\mathrm{R}^{2}$ assesses the explanative power of the model (Hair et al., 2017). $\mathrm{R}^{2}$ values $0.26,0.13$ and 0.02 are considered as substantial, moderate and weak respectively (Cohen, 1988) The results show that leadership, organizational culture and justice explain about $51 \%$ variance $\left(\mathrm{R}^{2}=0.514\right)$ in organizational commitment. Further, the commitment explains moderate to a substantial level of variance in OCB $\left(\mathrm{R}^{2}=0.241\right)$. Overall, it confirms an adequate explanative power of the model.

Next, $f^{2}$ is assessed to measure the specific exogenous construct's substantive impact on endogenous construct (Hair et al., 2017). $f^{2}$ values $0.35,0.15$ and 0.02 are regarded as substantial, moderate and weak respectively (Cohen, 1988). The results reveal that justice has a moderate to high effect $\left(f^{2}=0.216\right)$, whereas leadership $\left(f^{2}=0.028\right)$ and culture $\left(f^{2}=0.027\right)$ have a weak to moderate effect on organizational commitment. Moreover, organizational commitment is found to have a substantial effect on OCB $\left(f^{2}=0.325\right)$.

Table 3. Coefficient of determination and effect size

\begin{tabular}{ccccc}
\hline \hline Latent Constructs & \multicolumn{2}{c}{$\boldsymbol{R}^{\mathbf{2}}$} & \multicolumn{2}{c}{$\boldsymbol{f}^{2}$} \\
\hline Commitment $\rightarrow$ OCB & 0.246 & Moderate & 0.325 & Substantial \\
Justice $\rightarrow$ Commitment & & & 0.216 & Moderate \\
Transformational Leadership $\rightarrow$ & 0.514 & Substantial & 0.028 & Weak \\
Commitment & & & 0.027 & Weak \\
Culture $\rightarrow$ Commitment & & &
\end{tabular}


Path coefficients which represent the hypothesized relationships are then assessed. As depicted in Table 4 , the results indicate that organizational culture $(\beta=.151, t=3.001, p=0.001)$, leadership style $(\beta=0.149, t=2.257, p=0.012)$, and organizational justice $(\beta=0.496, t=7.406, p=0.000)$ have positive impact on organizational commitment, thus concluding that $\mathrm{H} 1, \mathrm{H} 2$, and $\mathrm{H} 3$ are statistically significant and supported. Among these, organizational justice is observed as the strongest predictor of organizational commitment. Additionally, organizational commitment is also found to be a strong predictor of OCB $(\beta=0.496, t=9.569, p=0.000)$. For that reason, $\mathrm{H} 4$ is also supported.

Table 4: Results of Structural Model

\begin{tabular}{lccccccc}
\hline \hline Hypotheses & Beta & $S E$ & $t$-value & Sig. & $5 \%$ & $95 \%$ & Decision \\
\hline $\begin{array}{l}\text { H1: Culture } \rightarrow \\
\text { Commitment }\end{array}$ & 0.151 & 0.05 & 3.001 & 0.001 & 0.061 & 0.227 & Supported \\
$\begin{array}{l}\text { H2: } \\
\text { Transformational } \\
\text { leadership } \rightarrow\end{array}$ & & & & & & & \\
$\begin{array}{l}\text { Commitment } \\
\text { H3: Justice } \rightarrow\end{array}$ & 0.149 & 0.066 & 2.257 & 0.012 & 0.033 & 0.249 & \\
$\begin{array}{l}\text { Commitment } \\
\text { H4: Commitment } \\
\rightarrow \text { OCB }\end{array}$ & 0.496 & 0.067 & 7.406 & 0.000 & 0.382 & 0.602 & Supported \\
\hline \hline
\end{tabular}

As suggested by Memon, Cheah, Ramayah, Ting, and Chuah (2018), Preacher and Hayes's (2004, 2008) approach of indirect effect is adopted to test the mediating role of organizational commitment between independent variables (justice, leadership and culture) and OCB. The results of mediation analysis show that organizational justice $(\beta=0.246, t=5.416, p=0.000$, LL: 0.159, UL: 0.336), leadership ( $\beta=0.074, t=2.033, p=0.042$, LL: 0.008 , UL: 0.149$)$ and organizational culture $(\beta=0.075, t=2.774, p=0.006$, LL: 0.024, UL: 0.128$)$ have an indirect effect on OCB, thereby confirming the significance of organizational commitment as a mediator in the model. Therefore, H5, H6 and H7 are supported. The results of mediation analysis are presented in Table 5.

Table 5: Mediation Results

\begin{tabular}{llllllll}
\hline \hline Indirect Effect & Beta & $\boldsymbol{S E}$ & $\boldsymbol{t}$-value & Sig. & $\mathbf{2 . 5 0 \%}$ & $\mathbf{9 7 . 5 0 \%}$ & Decision \\
\hline $\begin{array}{l}\text { H5: Org Culture } \\
\rightarrow \text { Commitment } \\
\rightarrow \text { OCB }\end{array}$ & 0.075 & 0.027 & 2.774 & 0.006 & 0.024 & 0.128 & Supported \\
$\begin{array}{l}\text { H6: } \\
\text { Transformational }\end{array}$ & & & & & & & \\
$\begin{array}{l}\text { Leadership } \rightarrow \\
\text { Commitment } \rightarrow\end{array}$ & 0.074 & 0.036 & 2.033 & 0.042 & 0.008 & 0.149 & Supported \\
$\begin{array}{l}\text { OCB } \\
\text { H7: Justice } \rightarrow\end{array}$ & & & & & & & \\
$\begin{array}{l}\text { Commitment } \rightarrow \\
\text { OCB }\end{array}$ & 0.246 & 0.045 & 5.416 & 0.000 & 0.159 & 0.336 & Supported \\
\hline \hline
\end{tabular}




\section{DISCUSSION AND IMPLICATIONS}

This study confirms that organizational culture, transformational leadership, organizational justice, and organizational commitment have a noteworthy influence on OCB among faculty members in Malaysian private universities and on that account consistent with findings in previous studies. The influence of organizational culture on OCB among employees is consistent with those of earlier studies (Messner, 2013; Yiing \& Ahmad, 2009; Silverthorne, 2004). The findings suggest higher educational institutions which adopt a more laissez-faire approach play a crucial role in developing both organizational commitment and OCB among their faculty members. Majority of the faculty members in this study who are from Generation Y era typically exhibit innovativeness and dynamism which could easily be imparted into their students (Zhu \& Engels, 2017).

This study further unveils that transformational leadership is inherent in traits such as foresight, transformation, and motivation and they have profound impact on organizational commitment and OCB. This is also reflected in past studies, thus underlining the urgency of leadership style and recognition as stimuli towards facilitating OCB (Geijsel et al., 2003). Most significantly, this solidifies social exchange theory in illustrating the stature of reciprocity and leadership style in uplifting positive work outcomes.

Prior studies have delved into implementation of fair procedures (Joo et al., 2012; Messner, 2013) and shown how management effort to value the employees will have an exceptional effect on OCB (Crow, Lee, \& Joo, 2012; Hassan \& Hashim, 2011). Faculty members ought to develop trust with co-workers as evident in previous studies (Bashir \& Long, 2015; Hoy \& Tarter, 2004). To achieve competitive advantage, one recommended strategy would be for private higher education institutions to emphasize more on organizational culture, transformational leadership, and fair procedures internally.

The study confirms the positive effect of organizational culture, transformational leadership, and organizational justice on organizational commitment. Particularly, fairness is deemed pivotal to fostering trust among academics in a collectivist-based setting. Empathy should be apparent between faculty members and their affiliated institutions to strive for greater success in collective manner and thus avoid any issue related to inequality which may lead to a reduced level of OCB (Alfy \& David, 2017; Malik \& Naeem, 2011). Moreover, the effect of organizational commitment on OCB in the context of private universities in Malaysia, organizational commitment is also found to be a significant mediator of the hypothesized relationships, thus underscoring the relevance of organizational commitment in private universities in malaysia to facilitate organizational development and OCB in an increased competitive environment. Unlike public universities in Malaysia, private universities have less funding from the government and need to do a lot more to attract students every year (or every intake). Recruiting competent academics without ensuring they are committed to the institutions will be costly in the long run. They will fulfill the teaching hours and do the operational tasks in the short run but the absence of commitment will gradually result in a reduced OCB.

Overall, the study has added a new dimension in higher education organizational behaviour with the knowledge that organizational commitment among faculty members is an effective mediator 
in the relationship between organizational culture, transformational leadership, organizational justice and OCB. Drawing upon the essence of social exchange theory, reprocity is pivotal to the further development of higher education institutions. These institutions should pay special attention to organisational commitment because of its significant role to facilitate organizational development and OCB. Organisation culture for instance may have a positive influence on minimizing red tape and increasing innovativeness if the academics are committed, and it will surely lead to greater OCB. This is also applicable to transformational leadership and organisation justice. Transformational leadership may not be as effective if the academics are not committed to the vision, missions and objectives of the institutions (or leaders). In like manner, the academics' commitment to the institutions explains the strong or weak relationship between organization justice and OCB.

Most higher education institutions are operated inside a stable, predictable ecosystem that is wellknown to be recession-proof. This traditional paradigm may not be valid in today's fast-changing educational industry, including that of developing countries like Malaysia. Rather than managing in a highly bureaucratic environment, leaders in higher education institutions should be leaders of tomorrow by embracing change, prudent and possessing avant-garde mentality. Value-added practice such as additional consultation hours, personal coaching and innovative learning methodology are a worthy consideration for academics and faculty members in responding towards OCB. Those in the management must not be content in maintaining the status quo and achieving organizational objectives at the expense of human well-being.

\section{LIMITATIONS AND FUTURE DIRECTIONS}

Notwithstanding the novelty of the study, it has several limitations which require further consideration. Firstly, the data based on 324 observations were analyzed without controlling the potential confounding effect caused by the characteristics of the private universities or faculties and the academics. Secondly, given the nature of the issues, a qualitative approach to understand the how and why of OCB from the faculty members and those at the management level would likely elicit more insights. Thirdly, the inclusion of public universities will provide a more comprehensive understanding of the scenario of higher education in Malaysia and more meaningful implications to organizational commitment and OCB in private universities. It is thus surmised that further studies which look into heterogeneity issues as well as organizational commitment and OCB from multiple views are needed to extend the knowledge of the subject matter and yield a more practical and feasible approach to reinforcing OCB in the private universities.

\section{REFERENCES}

Ababaneh, R. I. (2010). The role of organisational culture on practicing quality improvement in Jordanian public hospitals. Leadership in Health Services, 23(3), 244-259.

Abi, J., \& Arief, M. (2017). Examining the Relationship between Transformational Leadership and Dynamic Capability to the Adoption of Digital Marketing in Consumer Shopping Good Firms. International Journal of Economics and Management, 11(S2), 487-504. 
Alfy, S. E., \& David, S. A. (2017). Investigating organisational justice in higher education in UAE. International Journal of Management Education, 11(2), 163-187.

Alondenene, R., \& Majauskaite, M. (2016). Leadership style and job satisfaction in higher education institution. International Journal of Education, 30, 1-10.

Altintas, F., Kurtulmusoglu, F. B., Altintas, M. H., Kaufmann, H.-R., \& Alkibay, S. (2017). The mediating effects of adaptive selling and commitment on the relationship between management control and sales performance. EuroMed Journal of Business, 12(2), 221240.

Anderson, J. C., \& Gerbing, D. W. (1988). Structural equation modelling in practice: a review and recommended two-step approach. Psychological Bulletin, 103(3), 411-423.

Asgari, A., Silong, A. D., Ahmad, A., \& Samah, B. A. (2008). The Relationship Between Transformational Leadership Behaviours, Organization Justice,Leader Member Exchange,Perceived Organizational Support, Trust in Management and organization Citizenship Behavior. Euro Journals Publishing, 23, 227-242.

Barbuto, J., \& Story, J. S. P. (2011). Work motivation and organisational citizenship behaviour: A Field Study. Journal of Leadership styles, 5(1), 23-34.

Bashir, N., \& Long, C. S. (2015). The relationship between training and organizational commitment anibg academicians in Malaysia. Journal of Management Development, 34(10), 1227-1245.

Blau, P. M. (2009). Exchange and power in social life. New York: John Wiley \& Sons

Bryman, A. (2007). Effective leadership in higher education: A literature review. Studies in Higher Education, 32(6), 693-710.

Chang K., Nguyen B., Cheng K. T., Kuo C. C., \& Lee I. (2016). HR practice, organisational commitment and citizenship behaviour. Employee Relations, 38, 907-926.

Choong, K. F., Wong, E. S. K., \& Tioh, N. H. (2010). The impact of organizational justice on employees job satisfaction: The Malaysian companies perspective. American Journal of Economics and Business Administration, 2(1), 56-63.

Cohen, J. (1988). Statistical power analysis for the behavioral sciences $\left(2^{\text {nd }}\right.$ ed.). New Jersey: Lawrence Erlbaum.

Crow, M. S., Lee, C.-B., \& Joo, J.-J. (2012). Organisational Justice and organisational commitment among south korean police officers: An investigation of job satisfaction as a mediator. Journal of Police Strategies and Management, 35(2), 402-423.

Elstad, E., Christophersen, K.-A., \& Turmo, A. (2012). The strength of accountability and teacher's organisational citizenship behavior. Journal of Educational Administration, 50(5), 612-628.

Farzaneh, J., Farashah, A. D., \& Kazemi, M. (2014). The impact of person job for and person organisation fit on OCB: The mediating and moderating effects of organisational commitment and psychological empowerment. Personnel Review, 43(5), 672-691.

Flinders, N. T., \& Rauter, K. A. (2004). Organizational citizenship behaviours in relation to job status,job insecurity,organisational commitment and identification,job satisfaction and work values. Journal of Occupational and Organisational Policy, 77, 81-94.

Geijsel, F., Sleegers, P., Leithwood, K., \& Jantzi, D. (2003). Transformational Leadership Effects on Teachers Commitment and Effort Toward School Reform. Journal of Educational Administration, 41, 228-256.

Glinow, M. V. (2010). Organizational Behaviour, Emerging Knowledge and Practice for The Real World (5 ${ }^{\text {th }}$ ed.). New York: McGraw Hill, Irwin 
Graen, G. B., \& Uhl-Bien, M. (1995). Relationship based approach to leadership development of leader member exchange theory of leadership over 25 years: Applying multi level multi domain perspective. Leadership Quartely, 6, 219-247.

Gyensare, M. A., Tsede, O. A., Sanda, M. A., \& Okpoti, C. A. (2016). Transformational leadership and employee turnover intention: The mediating role of affective commitment. World Journal of Entrepreneurship, Management and Sustainable Development, 12(3), 243-266.

Hair, J. F., Hult, G. T. M., Ringle, C. M., \& Sarstedt, M. (2014). A Primer on Partial Least Squares Structural Equation Modeling (PLS-SEM). Los Angeles: USA: SAGE.

Hair, J. F., Hult, G. T. M., Ringle, C. M., \& Sarstedt, M. (2017). A primer on partial least squares structural equation modeling (PLS-SEM) $\left(2^{\text {nd }}\right.$ ed.). Thousand Oaks, CA: Sage.

Hassan, A., \& Hashim, J. (2011). Role of organisational justice in determining work outcomes of national and expatriate academic staff in Malaysia. International Journal of Commerce and Management, 21(1), 82-93.

Henseler, J., Ringle, C. M., \& Sarstedt, M. (2015). A new criterion for assessing discriminant validity in variance-based structural equation modeling. Journal of the Academy of Marketing Science, 43(1), 115-135. doi:10.1007/s11747-014-0403-8

Hoy, W. K., \& Tarter, J. (2004). Organisational justice in schools:no justice without trust. International Journal of Educational Management, 18(4), 250-259.

Hofstede, G., Hofstede, G. J., \& Minkov, M. (2010). Cultures and Organizations: Software of the Mind. New York: McGraw-Hill.

Hofstede, G., Neuijen, B., Ohayv, D. D., \& Sanders, G. (1990). Measuring Organizational Cultures: A qualitative and quantitative study across twenty cases. Administrative Science quartely, 35, 286-316.

Jain, A. K. (2016). Volunteerism, affective commitment and citizenship behaviour: An empirical study in India. Journal of Managerial Psychology, 31(3), 657-671.

Jain, A. K., Giga, S. I., \& Cooper, C. L. (2013). Perceived organisational support as a moderator in the relationship between organisational stressors and organisational citizenship behavior. International Journal of Organisational Analysis, 21(3), 313-334.

Joo, B. K., Yoon, H. J., \& Jeung, C. W. (2012). The effects of core self-evaluations and transformational leadership in organisational commitment. Leadership and Organization Development Journal, 33(6), 564-582.

Kagaari, J. R. K., \& Munene, J. C. (2007). Engineering Lecturers Competencies and Organizational Citizenship at Kyambogo University. Journal of European Industrial Training, 21, 706-726.

Keskes, I., Sallan, J. M., Simo, P., \& Fernandez, V. (2018). Transformational leadership and organizational commitment: Mediating role of leader-member exchange. Journal of Management Development, 37(3), 271-284.

Khalili, A. (2017). Transformational leadership and organizational citizenship behaviour: The moderating role of emotional intelligence. Leadership and Organization Development Journal, 38(7), 1004-1015.

Khan, S., \& Rashid, M. Z. (2012). The Mediating effect of organisaitonal commitment in the organisation culture, leadership and organisational justice relationship with organisational citizenship behaviour: A Study of academicians in private higher learning institutions. International Journal of Business and Social Science, 3(8), 83-91. 
Khalifa, B. \& Ayoubi, R. M. (2015). Leadership styles at Syrian higher education: What matters for organizational learning at public and private universities International Journal of Educational Management, 29, 477-491.

Lapierre, L., \& Hackett, R. (2007). Trait conscientiousness, leader-member exchange,job satisfaction and organizational citizenship behavior. A test of an integrative model. Journal of Occupational and Organizational Psychology, 80, 539-554.

Lau, P. Y. Y., McLean, G. N., Lien, B. Y.-H., \& Hsu, Y.-C. (2016). Self rated and pee rated organisational citizenship behaviour, affective commitment, and intention to leave in a Malaysian context. Personnel Review, 45(3), 569-592.

Lazauskaite, J., Urbanaviciute, L., \& Bagdziuniene, D. (2015). The role of prosocial and intrinsic motivation in employees citizenship behaviour. Baltic Journal of Management, 10(3), $345-365$.

Lee, J. (2005). Effects of Leadership and Leader Member Exchange on Commitmen. Organizational Development Journal, 26, 655-672.

Li, Y. C. (2004). Examining the effect of organization culture and leadership behaviours on organizational commitment, job satisfaction and job performance at small and middlesized firms of Taiwan. Journal of American Academy of Business, 5(1/2), 432-438.

Liu, Y. (2009). Perceived Organizational Support and Expatriate Organization Citizenship Behavior: The Mediating Role of Affective Commitment Towards The Parent Company. Personnel Review, 38(3), 307-319.

Lo, M. C., Ramayah, T., \& Kueh, S. H. (2006). An investigation of leader member exchange effects on organisational citizenship behaviour in Malaysia. Journal of Business and Management, 12(1), 5-23.

Macfarlane, B. (2007). Defining and Rewarding Academic Citizenship: The implications for University Promotions Policy. Journal of Higher Education Policy and Management, 29(3), 261-273.

Malik, M. E., \& Naeem, B. (2011). Faculty members perceptions of organizational justice in institutes of higher learning of Pakistan. African Journal of Business Management, 5(16), 6698-6706.

Mathieu, J. E., \& Zajac, D. M. (1990). A Review and Meta-Analysis of the Antecedents, Correlates, Consequences of Organizational Commitment. Psychological Bulletin, 108(2), 171-194.

McCurdy, J. W. (2014). Organizational Commitment and job satisfaction: An examination of staff in higher education. (Publication No. 3617798) [Doctoral Dissertation, Claremont Graduate University]. ProQuest Dissertation Publishing.

McNeish, D. (2017). Thanks Coefficient Alpha, We'll Take It from Here. Psychological Methods, 1-23. doi:10.1037/met0000144

Mekpor, B., \& Baah, K. D. (2017). Leadership styles and employees' voluntary work behaviours in the Ghanaian banking sector. Leadership and Organization Development Journal, 38(1), 74-88.

Meyer, J. P., \& Allen, N. J. (1997). Commitment in The Workplace: Theory, Research and Application. California: Sage Publications.

Memon, M. A., Cheah, J. H., Ramayah, T., Ting, H., \& Chuah, F. (2018). Mediation analysis: Issues and recommendations. Journal of Applied Structural Equation Modeling, 2(1), i-ix.

Memon, M. A., Sallaeh, R., Baharom, M. N. R., Nordin, S. M., \& Ting, H. (2017). The relationship between training satisfaction, organisational citizenship behaviour, and turnover intention: A PLS-SEM approach. Journal of Organizational Effectiveness: People and Performance, 4(3), 267-290. 
Memon, M. A., Ting, H., Ramayah, T., Chuah, F., \& Cheah, J. H. (2017). A review of the methodological misconceptions and guidelines related to the application of structural equation modeling: A Malaysian scenario. Journal of Applied Structural Equation Modeling, 1(1), i-xiii.

Messner, W. (2013). Effect of organisational culture on employee commitment in the Indian IT services sourcing industries. Journal of Indian Business Research, 5(2), 76-100.

Mohammad, J., Quoquab, F., Makhbul, Z. M., \& Ramayah, T. (2016). Bridging the gap between justice and citizenship behaviour in Asian culture. Cross cultural and strategic management, 23(4), 633-656.

Nitzl, C., Roldan, J. L., \& Carrion, G. C. (2016). Mediation analysis in partial least squares path modelling: Helping researchers discuss more sophisticated models. Industrail Management \& Data Systems, 116(9), 1849-1864.

Ng, T. W. H. \& Feldman D. C. (2011). Affective organisational commitment and citizenship behaviour: Linear and non-linear moderating effects of organisational tenure. Journal of Vocational Behavior, 79, 528-537.

Oplatka, I. (2009). Organisational citizenship behaviour in teaching: The consequences for teachers, pupils and the school. International Journal of Educational Management, 23(5), 375-389.

Ortiz, M. Z., Rosario, E., \& Marquez, S. (2015). Relationship between organisation commitment and organisational citizenship behaviour in a sample of private banking employees. International Journal of Sociology and Social Policy, 35, 91-106.

Organ, D. W., Podsakoff, P., \& MacKenzie, S. (2006). Organisation citizenship behaviour: Its nature, antecedents and consequences. Thousand Oaks: Sage Publication.

Ozduran, A., \& Tanova, C. (2016). Coahing and employee organisational citizenship behaviours: The role of procedural justice climate. International Journal of Hospitality Management, 60, 58-66.

Perryer, C., \& Jordan, C. (2010). Predicting Turnover Intentions, The Interactive Effects of organisational commitment and perceived organisational support. Management Research Review, 33(9), 911-923.

Pillai, R., \& Williams, E. A. (2004). Transformational leadership, self-efficacy, group cohesiveness, commitment and performance. Journal of Organisational Change, 17(2), 144-159.

Podsakoff, N. P., \& Mackenzie, S. B. (1997). Impact of organizational citizenship behaviour on organisational performance: A review and suggestions for future research. Human Performance, 10(2), 133-151.

Podsakoff, N. P., Whiting, S. W., Podsakoff, P. M., \& Blume, B. D. (2009). Individual and organisational level consequences of organisational citizenship behaviours: A meta analysis. Journal of Applied Psychology, 94(1), 122-141.

Preacher, K. J., \& Hayes, A. F. (2004). SPSS and SAS procedures for estimating indirect effects in simple mediation models. Behavior Research Methods, Instruments, \& Computers, 36(4), 717-731.

Preacher, K. J., \& Hayes, A. F. (2008). Asymptotic and resampling strategies for assessing and comparing indirect effects in multiple mediator models. Behavior research methods, 40(3), 879-891.

Rafferty, A. E., \& Griffin, M. A. (2004). Dimension of transformational leadership:Conceptual and empirical extensions. The Leadership Quarterly, 15, 329-354. 
Ramayah, T., Cheah, J., Chuah, F., Ting, H., \& Memon, M. A. (2016). Partial Least Squares Structural Equation Modeling (PLS-SEM) using SmartPLS 3.0: An Updated Guide and Practical Guide to Statistical Analysis. Kuala Lumpur, Malaysia: Pearson.

Ramayah, T., Cheah, J., Chuah, F., Ting, H., \& Memon, M. A. (2018). Partial Least Squares Structural Equation Modeling (PLS-SEM) using SmartPLS 3.0: An Updated Guide and Practical Guide to Statistical Analysis (2 ${ }^{\text {nd }}$ ed.). Kuala Lumpur, Malaysia: Pearson.

Ringle, C. M., Wende, S., \& Becker, J. M. (2015). Smart PLS 3. Boenningstedt SmartPLS $\mathrm{GmbH}$. Retrieved from http://www.smartpls.com.

Vasayakin, B. S., Ivleva, M. I., Pozharskaya, Y. L., \& Shcherbakova, P. O. (2016). A Study of the Organisational Culture at Higher Education Institutions. International Journal of Environmental and Science Education, 11(10), 11515-11528.

Schein, E. (2004). Organisational culture and leadership. San Francisco: Jossey-Bass.

Somech, A. \& Bogler, R. (2002). Antecedents and consequences of teachers organisational and professional commitment. Educational Adminstration Quartely, 38, 555-577.

Somech, A. \& Drach-Zahavy, A. (2004). Exploring Organization Citizenship Behavior from an organization Perspective: The Relationship Between Organizational Learning and Organization Citizenship Behavior. Journal of Occupational and Organizational Psychology, 77, 281-298.

Silverthorne, C. (2004). The impact of organisation culture and person organisation fit on organisation commitment and job satisfaction in Taiwan. Leadership and Organization Development Journal, 25(7), 592-599.

Suliman, A. M. T. (2002). Is it really a mediating construct? The mediating role of organizational commitment in work climate performance relationship. Journal of Management Development, 21(3), 170-183.

Tan, J. X., Zawawi, D., \& Aziz Y. A. (2016). Benevolent Leadership and its organisational outcomes: A Social Exchange Theory Perspective. International Journal of Economics and Management, 10(2), 343-364.

Trivellas, P., \& Dargenidou, D. (2009). Organisational culture, job satisfaction and higher education service quality: The case of Technological Educational Institute of Larissa. The TQM Journal, 21(4), 382-399.

Limpanitgul, T., \& Boonchoo, P. (2017). Coworker support and organisational commitment.a comparative study of thai employees working in Thai and Americal Airlines. Journal of Hospitality and Tourism Management, 21, 100-107.

Uddin, M. A., Mahmood, M., \& Fan, L. (2019). Why individual employee engagement matters for team performance? Mediating effects of employee commitment and organizational citizenship behaviour. Team Performance Management: An International Journal, 25(1/2), 47-68.

Wallach, E. J. (1983). Individuals and Organizations: The Cultural Match. Training and Development Journals, 37(2), 28-36.

Yiing, L. H., \& Ahmad, K. Z. B. (2009). The Moderating Effects of Organization Culture on the Relationships between Organization Commitment. Job satisfaction and Performance. Leadership and Organization Development Journal, 30(1), 53-86.

Zhu, C., \& Engels, N. (2017). Organizational culture and instructional innovations in higher education: Perceptions and reactions of teachers and students. Educational Management Administration and Leadership, 42(1), 136-158. 